\title{
Accounting
}

\section{Political turmoil and banks' stock returns: Evidence from Turkey's 2016 coup attempt}

\author{
Khaled Alsaifi $^{a^{*}}$, Abdullah M. Al-Awadhi ${ }^{\mathrm{a}}$ and Salah Alhammadi $^{\mathrm{b}}$
}

${ }^{a}$ College of Business Studies, Public Authority for Applied Education and Training (PAAET), Kuwait

${ }^{b}$ College of Business Administration, Gulf University of Science and Technology, Kuwait

\begin{tabular}{l}
\hline C H R O N I C L E \\
\hline Article history: \\
Received May 152020 \\
Received in revised format May \\
162020 \\
Accepted June 292020 \\
Available online \\
July 42020 \\
\hline Keywords: \\
Coup Attempt \\
Istanbul Stock Exchange (ISE) \\
Banks Index \\
Event Study Method \\
State of Emergency \\
\hline
\end{tabular}

A B S T R A C T

\begin{abstract}
Turkey experienced an extreme political event on Friday July 152016 in the form of an attempted coup. This paper examines the impact of this event on the components of the Banks Index of the Istanbul Stock Exchange using event study methodology. Results show that the banks' abnormal returns (ARs) were a statistically significant negative from +2 to +6 days with the peak on day +3 when the government declared a state of emergency. Furthermore, when the banks' stocks are compared with the overall market, they display lower volatility during the study period. These findings evidence the importance attached to political factors and particularly political instability in shaping investment decision making.
\end{abstract}

\section{Introduction}

C 2020 by the authors; licensee Growing Science, Canada

Political events are known to be a source of stock market volatility due to the uncertainty they bring (e.g. Bash \& Alsaifi 2019; Günay, 2019). Turkey is one country that has experienced political turbulence and has been the subject of studies of stock market impacts. These studies have generally used the banking institutions listed in the Istanbul Stock Exchange (ISE) that constitute the Banks Index. While political instability is associated with reduced investment, there is a lack of evidence regarding the specific impact of the Turkish attempted coup of 2016 on the ISE. Therefore, providing evidence to fill this research gap would contribute significantly to the literature. Furthermore, banks are often excluded from stock return studies on the basis they are different in important respects from non-financial stocks, reducing the available literature on this important sector (European Central Bank, 2006). With this motivation, we analyze the listed stocks on the Banks Index of the ISE to examine the effect of the coup on banks' returns. Focusing on the banking sector is justified by the commanding role they play in providing business investment in the country (Kartal et al., 2018) and their success in attracting foreign direct capital flows which has contributed to the rising value of bank stocks (Acar \& Temiz, 2017). On Friday July 15, 2016, a military coup was attempted to overthrow the Turkish government. It started after the stock market had closed and had been quashed within just a few hours (BBC News, 2016a). The government declared a state of emergency on Thursday July 212016 (BBC News, 2016b). A military coup is an extreme political event and can be expected to lead to rapid and highly negative investor reaction. Section 2 presents a review of the literature on political crises and stock returns. Section 3 presents the research design, followed by Section 4, which shows the research results and discussion. Section 5 concludes.

* Corresponding author.

E-mail address: km.alsaifi@paaet.edu.kw (K. Alsaifi) 


\section{Literature Review}

Political risk is a component of financial risk alongside market risk, credit risk and operational risk and is particularly significant in emerging economies (Günay, 2016, 2019). The political domain has long been understood to be an important part of the external environment in which businesses operate (Aguilar, 1967). Most of the time, this domain affects a business when a government interacts with the economy, such as when it regulates or when it determines the balance between public and private sectors. In addition to the ongoing significance of politics, there are periods when the political domain has a more acute effect on businesses. These political events can be extreme in their impact. An example of an extreme political event is an attempted coup such as the one experienced by Turkey on Friday July 15 2016. An unsuccessful coup is an indicator of political instability, alongside others including terrorist attacks, the detention of opposition leaders, riots, protests, and media censorship (Jadallah $\&$ Bhatti, 2019). Changes of government as a result of a democratic process effect economic growth positively while undemocratic regime change has a negative effect (Feng, 1997). The literature has examined a broad range of political events for their effects on stock market returns, including both multi-country and single country effects. Amihud and Wohl (2004) found a strong effect on stock prices from the anticipation of Saddam Hussein's fall from power in 2003, suggesting that it was associated with ending a costly and destabilizing war. Chen and Siems (2004) examined the historical effect of terrorism on stock markets, finding a significant negative effect on returns. The Iraq war was also associated with increased risks and causing a fall in equity prices and U.S. treasury yields (Rigobon \& Sack, 2005). The September 11, 2001, terrorist attacks on the U.S. have also been investigated for their effect on risk perception and tail dependence (Straetmans et al., 2008). Using a worldwide dataset of 447 political crises, Berkman et al. (2011) report that the beginning of a crisis is associated with increased stock market volatility and conversely the ending of a crisis sees reduced market volatility. The Brexit referendum, held in the U.K., is another political event that had a significantly negative effect on stock returns in many countries (Arora, 2017). The Brexit effect on stock market returns across a large number of indices was also confirmed by Burdekin et al. (2017).

There are also single country studies on political crises and stock market returns. On March 1, 2003, Turkey's parliament effectively blocked the U.S. from stationing military forces on its soil, a highly significant political event. Aktas and Oncu (2006) found that the investor reaction to this event supported the efficient market hypothesis as the market responded appropriately to new information resulting in neither an overreaction nor an underreaction. The Arab Spring, starting in January 2011, was a period of political instability in the Arab world. It was to have a sustained negative effect on stock returns in some countries. For example, in Egypt, from January 2011 to January 2012, half the value of the benchmark index, the EGX 30, had been wiped out (Lehkonen \& Heimonen, 2015). Ayub (2017) examined the effect of Pakistan president Benazir Bhutto's December 2007 assassination on the Karachi Stock Exchange. He found that while this unexpected political event caused a large drop in stock values on the first trading day, over the longer term there was no significant underreaction or overrection indicated. The uncertainty surrounding the disappearance of Jamal Khashoggi on October 2, 2018, was found to have a strongly negative effect on stock returns on firms listed on the Saudi Stock Exchange (Bash \& Alsaifi, 2019). However, not all political events lead to such a sustained reaction. The negative effect of Thailand's military coup on September 19, 2006, on the SET index lasted only minutes, and by the end of the first trading day, the index was up 3.1\% (Lehkonen \& Heimonen, 2015). The event had brought an extended period of political crisis to an end (Hewison, 2008) suggesting investors viewed the coup as a return to stability and therefore, a positive influence on investment. The banking sector is unsurprisingly one of substantial research interest due to its strategic role and potential for knock-on effects across the whole economy (Mirzaei et al., 2014; Motamedi, 2013). Banking sector returns are significantly and positively associated with future economic growth in both developed and emerging economies (Cole et al., 2008). As a highly regulated sector, banking is particularly sensitive to some aspects of the political dimension; however, studies of bank returns in volatile markets have tended to focus on financial crises rather than political ones (Cornett et al., 2009; Peni \& Vähämaa, 2012; Weigand, 2016). The extent to which banks' stock returns are affected by market volatility could be dependent on their size as some of the larger banks may be considered too big to fail (Chira et al., 2013). In summary, political crises and political events of varying kinds are known to be associated with abnormal stock returns and market volatility. The precise nature of investor reaction to political events appears from the evidence to be dependent on type of event, context, and the availability of new information. Short term reaction, particularly on the first trading day, and potentially based on herding behaviour (Sinha, 2015) may be misaligned with informed medium and longer-term investor reaction.

\section{Research Design}

Market efficiency assumptions dictate that event effects are immediately reflected in firms' stock price. Thus, the banks' returns following Turkey's coup attempt is estimated using the event study method. Under this approach means and medians are used for estimating banks' returns related to specific events (Alsaifi et al., 2020). The first task for an event study is determining the appropriate study period; this period will be used for estimating abnormal returns (ARs). The coup date of July 152016 would normally be designated as day 0 ; however, as the coup commenced after the market had closed, day 0 becomes the next trading day which was Monday July 182016 . All other trading days are designated in relation to day 0 . Hence the immediately preceding 
trading day is day -1 and the immediately subsequent trading day is day +1 . The estimation period extended from day -200 to day -21 . The 21 trading day gap between the end of the estimation period and day 0 is to eliminate any chance of contamination from the event and mitigate any stationarity. Data is obtained from Thomson Reuters for 12 banks that constitute the Banks Index on ISE during the examined period. We calculate the daily returns using simple arithmetic returns based on closing stock prices. Following Brown and Warner (1985) we apply the standard mean-adjusted returns when calculating the ARs for stock $i$ at Day $t$ :

$$
\begin{aligned}
& A R_{i, t}=R_{i, t}-\bar{R}_{i}, \\
& \bar{R}_{i}=\frac{1}{179}=\sum_{t=-200}^{-21} R_{i, t},
\end{aligned}
$$

where $R_{i, t}$ is the stock return $i$ at day $t$, and $\bar{R}_{i}$ is the average return of stock $i$ 's daily returns during the estimation period $(-200,-21)$. After this, we use the T-test for parametric testing, determining the statistical significance of the mean of ARs. Secondly, for non-parametric, we control for the effect of outliers with the Wilcoxon signed-rank test (W-test), determining the statistical significance of the median of ARs.

\section{Results and Discussion}

Descriptive statistics of the research sample use day -1 data, the day immediately before the day of the attempted coup, as shown in Table 1. In Turkish Lira (TL), the mean market capitalization and total assets were TL160.3 and TL156.7 billion respectively, suggesting our sample consists of large banks. Table 1 also indicates a wide variation in the banks' characteristics; however, the sample is weighted towards banks with a high market capitalization.

Table 1

\begin{tabular}{|c|c|c|c|c|c|}
\hline & Market Value (M) & Total Assets (M) & Sales (M) & Net Income (M) & Employees \\
\hline Mean & 160,305 & 156,715 & 3,886 & 653 & 15,248 \\
\hline Median & 190,510 & 200,195 & 5,023 & 602 & 15,363 \\
\hline SD & 112,676 & 123,779 & 3,080 & 583 & 7,529 \\
\hline Max & 306,703 & 341,821 & 8,668 & 1,536 & 25,079 \\
\hline Min & 7,230 & 7,051 & 120 & 5 & 825 \\
\hline
\end{tabular}

Descriptive statistics of the research sample

Table 2

\begin{tabular}{|c|c|c|c|c|c|c|c|c|c|c|}
\hline Day & Date & $\mathrm{N}$ & Mean & Median & Skewness & Kurtosis & Min & Max & T-test & W-test \\
\hline-10 & $6 / 29$ & 12 & $-0.634 \%$ & $-0.281 \%$ & -1.729 & 6.561 & $-11.988 \%$ & $4.672 \%$ & -0.578 & -0.454 \\
\hline-9 & $6 / 30$ & 12 & $-0.495 \%$ & $-0.186 \%$ & -1.776 & 6.709 & $-12.588 \%$ & $4.872 \%$ & -0.427 & -0.314 \\
\hline-8 & $7 / 1$ & 12 & $-0.257 \%$ & $0.243 \%$ & -1.739 & 6.588 & $-12.388 \%$ & $5.530 \%$ & -0.219 & 0.384 \\
\hline-7 & $7 / 4$ & 12 & $-0.088 \%$ & $0.713 \%$ & -1.796 & 6.751 & $-12.488 \%$ & $5.930 \%$ & -0.073 & 0.664 \\
\hline-6 & $7 / 8$ & 12 & $-0.172 \%$ & $0.513 \%$ & -2.013 & 7.161 & $-12.988 \%$ & $5.030 \%$ & -0.143 & 0.664 \\
\hline-5 & $7 / 11$ & 12 & $0.474 \%$ & $0.919 \%$ & -1.713 & 6.089 & $-11.488 \%$ & $5.630 \%$ & 0.404 & 1.083 \\
\hline-4 & $7 / 12$ & 12 & $1.628 \%$ & $1.313 \%$ & -0.361 & 3.400 & $-8.188 \%$ & $9.330 \%$ & 1.340 & 1.433 \\
\hline-3 & $7 / 13$ & 12 & $1.743 \%$ & $1.237 \%$ & 0.081 & 2.842 & $-5.888 \%$ & $9.330 \%$ & 1.600 & 1.433 \\
\hline-2 & $7 / 14$ & 12 & $2.005 \%$ & $1.337 \%$ & 0.199 & 2.487 & $-5.188 \%$ & $9.430 \%$ & 1.808 & 1.642 \\
\hline-1 & $7 / 15$ & 12 & $2.212 \%$ & $1.237 \%$ & 0.346 & 2.394 & $-4.688 \%$ & $10.130 \%$ & 1.924 & 1.642 \\
\hline $\mathbf{0}$ & $7 / 18$ & 12 & $-0.811 \%$ & $0.219 \%$ & -2.237 & 7.804 & $-13.988 \%$ & $4.130 \%$ & -0.672 & 0.035 \\
\hline+1 & $7 / 19$ & 12 & $-1.141 \%$ & $-0.257 \%$ & -2.282 & 7.891 & $-13.188 \%$ & $2.772 \%$ & -1.040 & -0.664 \\
\hline+2 & $7 / 20$ & 12 & $-2.026 \%$ & $-1.086 \%$ & -2.384 & 8.352 & $-15.988 \%$ & $2.972 \%$ & $-1.614^{*}$ & $-1.992 * *$ \\
\hline+3 & $7 / 21$ & 12 & $-3.757 \%$ & $-2.670 \%$ & -2.511 & 8.661 & $-22.788 \%$ & $1.472 \%$ & $-2.221 * *$ & $-2.691 * * *$ \\
\hline+4 & $7 / 22$ & 12 & $-3.641 \%$ & $-2.993 \%$ & -2.503 & 8.698 & $-23.088 \%$ & $2.272 \%$ & $-2.108 * *$ & $-2.621 * * *$ \\
\hline+5 & $7 / 25$ & 12 & $-2.618 \%$ & $-1.586 \%$ & -2.514 & 8.838 & $-20.588 \%$ & $3.572 \%$ & $-1.646^{*}$ & $-2.062 * *$ \\
\hline+6 & $7 / 26$ & 12 & $-2.941 \%$ & $-2.059 \%$ & -2.368 & 8.368 & $-21.488 \%$ & $3.972 \%$ & $-1.764 *$ & $-2.062 * *$ \\
\hline+7 & $7 / 27$ & 12 & $-2.018 \%$ & $-1.359 \%$ & -1.955 & 7.277 & $-19.988 \%$ & $5.237 \%$ & -1.198 & -1.503 \\
\hline+8 & $7 / 28$ & 12 & $-1.895 \%$ & $-1.170 \%$ & -1.834 & 6.987 & $-19.888 \%$ & $6.137 \%$ & -1.109 & -1.503 \\
\hline+9 & $7 / 29$ & 12 & $-1.672 \%$ & $-0.270 \%$ & -1.948 & 7.185 & $-19.388 \%$ & $5.537 \%$ & -1.004 & -1.083 \\
\hline+10 & $8 / 1$ & 12 & $-1.180 \%$ & $-0.257 \%$ & -1.831 & 6.958 & $-18.188 \%$ & $6.637 \%$ & -0.730 & -0.734 \\
\hline+11 & $8 / 2$ & 12 & $-1.588 \%$ & $-0.770 \%$ & -1.898 & 7.124 & $-16.588 \%$ & $4.937 \%$ & -1.122 & -1.433 \\
\hline+12 & $8 / 3$ & 12 & $-2.288 \%$ & $-1.870 \%$ & -2.112 & 7.651 & $-19.388 \%$ & $4.072 \%$ & -1.450 & -1.572 \\
\hline+13 & $8 / 4$ & 12 & $-1.303 \%$ & $-0.859 \%$ & -2.044 & 7.406 & $-15.988 \%$ & $4.337 \%$ & -0.953 & -1.013 \\
\hline+14 & $8 / 5$ & 12 & $-1.311 \%$ & $-0.340 \%$ & -1.989 & 7.286 & $-15.888 \%$ & $4.872 \%$ & -0.961 & -1.223 \\
\hline+15 & $8 / 8$ & 12 & $-0.211 \%$ & $-0.057 \%$ & -1.554 & 5.696 & $-12.588 \%$ & $5.472 \%$ & -0.170 & 0.384 \\
\hline+16 & $8 / 9$ & 12 & $0.289 \%$ & $0.243 \%$ & -1.102 & 4.382 & $-9.788 \%$ & $5.372 \%$ & 0.264 & 0.664 \\
\hline+17 & $8 / 10$ & 12 & $-0.418 \%$ & $0.019 \%$ & -1.476 & 5.621 & $-11.888 \%$ & $5.172 \%$ & -0.362 & 0.175 \\
\hline+18 & $8 / 11$ & 12 & $0.151 \%$ & $0.419 \%$ & -1.286 & 4.774 & $-10.388 \%$ & $5.172 \%$ & 0.136 & 0.664 \\
\hline+19 & $8 / 12$ & 12 & $-0.180 \%$ & $0.219 \%$ & -1.398 & 5.265 & $-11.188 \%$ & $5.272 \%$ & -0.159 & 0.384 \\
\hline+20 & $8 / 15$ & 12 & $-0.126 \%$ & $0.019 \%$ & -1.269 & 4.867 & $-10.388 \%$ & $5.172 \%$ & -0.117 & 0.454 \\
\hline
\end{tabular}

Key statistical indicators for banks' ARs 
Table 2 presents the key statistical indicators for banks' ARs from days -10 to +20 . With the market closed because of the weekend, investors first opportunity to react to the coup came on Monday July 182016 by which time the coup had ended more than 48 hours ago. The Turkish government had moved quickly to reassure the markets offering, through the Central Bank of Turkey, unlimited liquidity (Koc et al., 2016). We find the banks' ARs were statistically insignificant on the first two days of trading after the market had reopened. This may be because of the weekend effect which shock absorbed and because the coup was so short-lived. On day +3 , a state of emergency was announced, and a major suppression of government opponents began including mass arrests and purges (BBC News, 2016b). The announcement on day +3 coincides with the peak of negative and highly statistically significant ARs in both tests (i.e T-test and W-test) within the period +2 and +6 that saw a major sell-off and falling prices reflecting investors fear and uncertainty. Beyond this period, confidence returned to the markets including the currency markets where the Turkish Lira had now stabilized. After day +6 , while the ARs were still negative, they were not statistically significantly so in both tests. The other statistical indications presented in Table 2 shows the ARs distribution starts to be negatively skewed all days after the attempted coup, indicating the presence of negative outliers. It can also be seen that ARs distribution jumped to be leptokurtic for most days after the attempted coup, confirming extreme values of negative ARs. Fig. 1 shows the banks' ARs based on mean and median during the examined period. The dramatic drop in their value starting from day 0 , and their curves stayed in the negative area continuously till day +15 .

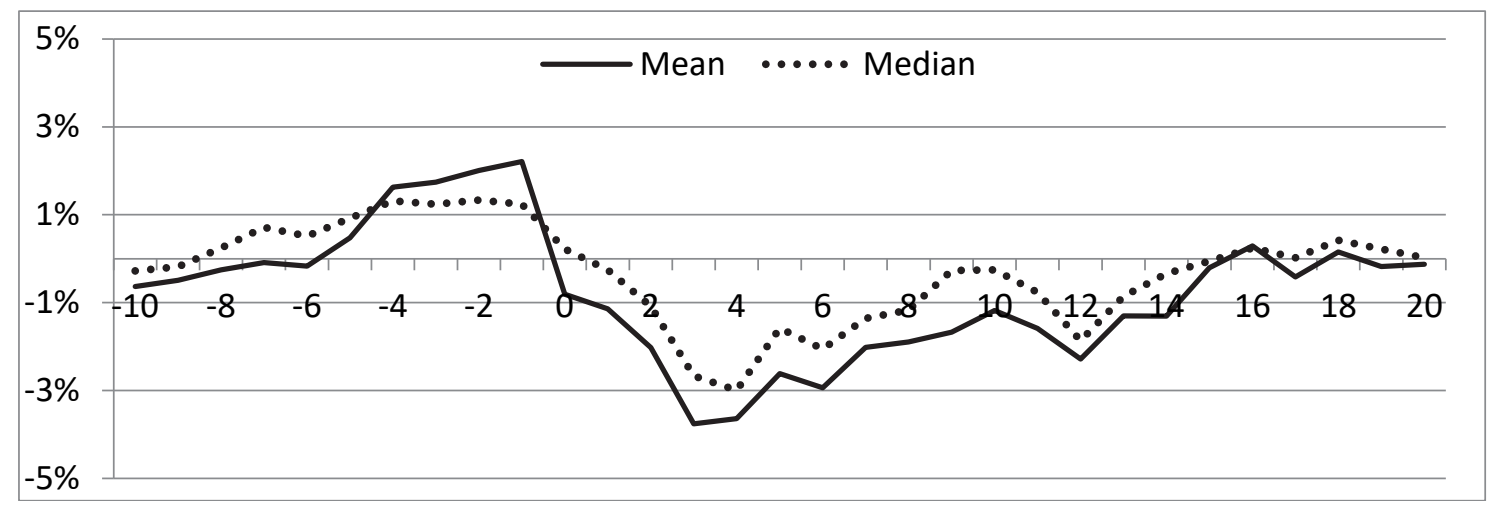

Fig. 1. The banks' ARs based on mean and median values.

Fig. 2 compares the ARs of banks, BIST100 and BIST30 components based on mean value. ${ }^{1}$ Although there is a drop in banks' ARs, there is an obvious difference between the sloping curves of banks' ARs and the other two samples. The decline in the ARs of banks' looks relatively smooth compared to the sharp declines seen in the ARs of the BIST100 and BIST30 components, specifically in the period from day 0 to +6 . The same outcome can be derived from Fig. 3, which shows that the ARs based on median value of banks' are less volatile compared to the components of BIST100 and BIST30.

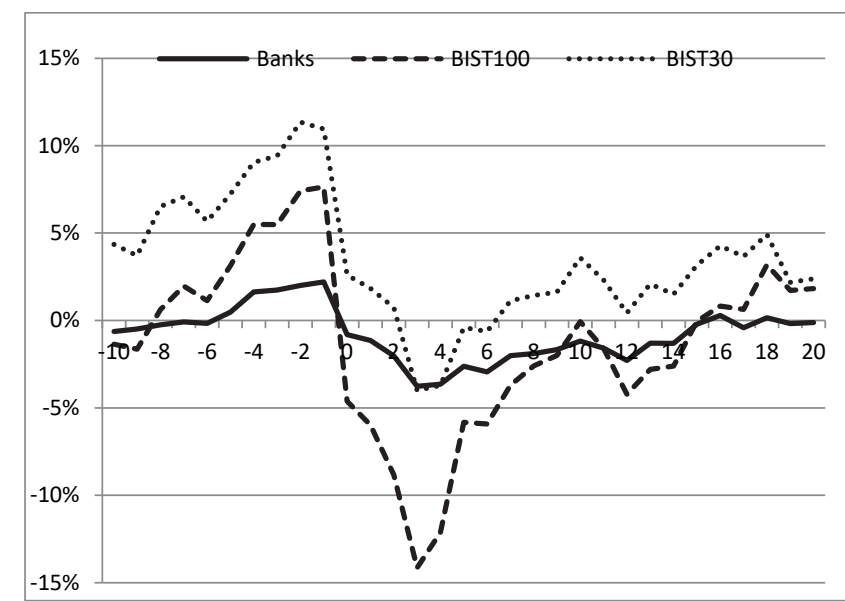

Fig. 2. The ARs of banks, BIST100 and BIST30 components based on mean value

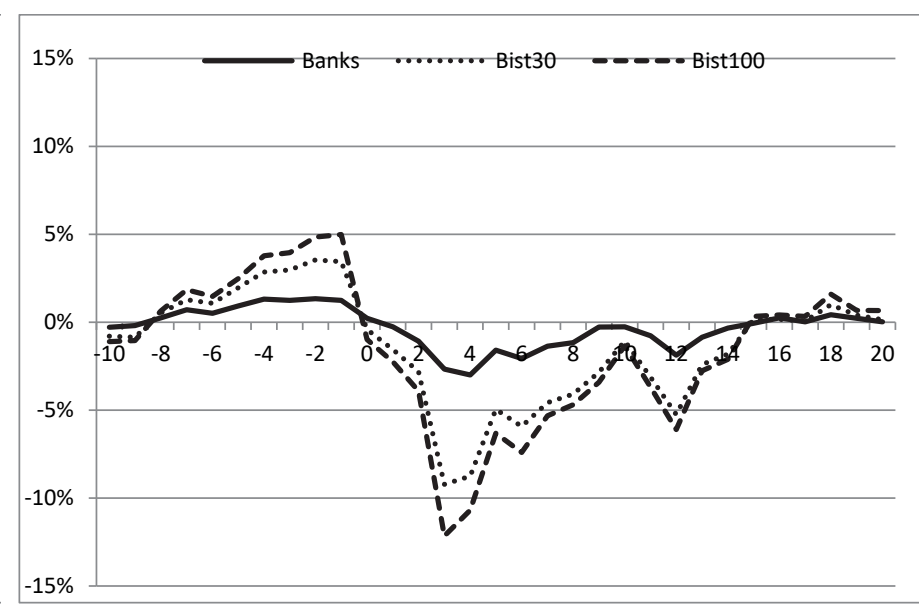

Fig. 3. The ARs of banks, BIST100 and BIST30 components based on median value

${ }^{1}$ The Borsa Istanbul National 100 Index (BIST100) and the Borsa Istanbul National 30 Index (BIST30) are market capitalization weighted indices comprising National Market companies with the exception of investment trusts. They are owned and operated by the Borsa İstanbul Group (Borsa İstanbul, 2019). 
An additional analysis presented in Table 3 shows the raw trading data of the Banks Index during the examined period. The results are confirmed, through the trading volume in TL and the negative percentage change in the Banks Index on days 0 and +3 (the first trading day and the day of declared the state of emergency) as these characteristics are the highest on those two days.

\section{Table 3}

Raw trading data for Banks Index

\begin{tabular}{|c|c|c|c|c|c|c|c|}
\hline Day & Date & Banks Index & Open & High & Low & Vol TL & Change \% \\
\hline-10 & $6 / 29$ & $128,561.03$ & $130,010.65$ & $130,627.46$ & $128,342.16$ & $323.82 \mathrm{M}$ & $-1.17 \%$ \\
\hline-9 & $6 / 30$ & $129,405.76$ & $128,815.01$ & $130,036.37$ & $128,389.38$ & $227.78 \mathrm{M}$ & $0.66 \%$ \\
\hline-8 & $7 / 1$ & $131,092.23$ & $130,012.05$ & $131,355.16$ & $129,940.03$ & $162.63 \mathrm{M}$ & $1.30 \%$ \\
\hline-7 & $7 / 4$ & $132,063.16$ & $131,341.98$ & $132,063.16$ & $131,042.16$ & $50.02 \mathrm{M}$ & $0.74 \%$ \\
\hline-6 & $7 / 8$ & $131,638.36$ & $131,793.73$ & $132,180.56$ & $131,203.67$ & $155.91 \mathrm{M}$ & $-0.32 \%$ \\
\hline-5 & $7 / 11$ & $133,809.55$ & $132,817.45$ & $133,959.23$ & $132,776.66$ & $201.65 \mathrm{M}$ & $1.65 \%$ \\
\hline-4 & $7 / 12$ & $138,987.55$ & $134,119.72$ & $139,050.36$ & $133,958.48$ & $374.35 \mathrm{M}$ & $3.87 \%$ \\
\hline-3 & $7 / 13$ & $139,221.63$ & $139,194.73$ & $140,303.63$ & $138,573.02$ & $279.44 \mathrm{M}$ & $0.17 \%$ \\
\hline-2 & $7 / 14$ & $140,346.25$ & $139,974.48$ & $140,860.91$ & $138,653.70$ & $267.94 \mathrm{M}$ & $0.81 \%$ \\
\hline-1 & $7 / 15$ & $141,487.70$ & $140,168.80$ & $141,602.13$ & $139,673.41$ & $217.41 \mathrm{M}$ & $0.81 \%$ \\
\hline 0 & $7 / 18$ & $129,597.82$ & $138,699.98$ & $138,699.98$ & $125,891.60$ & $546.54 \mathrm{M}$ & $-8.40 \%$ \\
\hline+1 & $7 / 19$ & $126,983.24$ & $127,933.34$ & $131,858.64$ & $126,332.81$ & $518.89 \mathrm{M}$ & $-2.02 \%$ \\
\hline+2 & $7 / 20$ & $123,141.87$ & $127,948.50$ & $128,402.89$ & $123,141.87$ & $432.60 \mathrm{M}$ & $-3.03 \%$ \\
\hline+3 & $7 / 21$ & $117,340.32$ & $122,195.49$ & $122,195.49$ & $117,173.98$ & $476.51 \mathrm{M}$ & $-4.71 \%$ \\
\hline+4 & $7 / 22$ & $117,651.15$ & $118,847.18$ & $119,642.94$ & $115,275.97$ & $391.71 \mathrm{M}$ & $0.26 \%$ \\
\hline+5 & $7 / 25$ & $121,429.56$ & $118,802.18$ & $121,775.14$ & $118,802.18$ & $304.46 \mathrm{M}$ & $3.21 \%$ \\
\hline+6 & $7 / 26$ & $119,572.28$ & $122,300.10$ & $122,613.15$ & $118,893.78$ & $277.26 \mathrm{M}$ & $-1.53 \%$ \\
\hline+7 & $7 / 27$ & $122,115.48$ & $120,119.98$ & $122,194.28$ & $119,880.15$ & $272.26 \mathrm{M}$ & $2.13 \%$ \\
\hline+8 & $7 / 28$ & $121,896.62$ & $123,202.73$ & $123,765.90$ & $121,229.76$ & $258.23 \mathrm{M}$ & $-0.18 \%$ \\
\hline+9 & $7 / 29$ & $123,156.06$ & $122,270.78$ & $123,622.41$ & $120,875.95$ & $243.69 \mathrm{M}$ & $1.03 \%$ \\
\hline+10 & $8 / 1$ & $125,158.95$ & $124,572.74$ & $125,608.54$ & $124,039.90$ & $213.67 \mathrm{M}$ & $1.63 \%$ \\
\hline+11 & $8 / 2$ & $123,540.21$ & $125,032.02$ & $125,640.85$ & $123,471.36$ & $254.98 \mathrm{M}$ & $-1.29 \%$ \\
\hline+12 & $8 / 3$ & $121,223.44$ & $123,224.37$ & $123,572.01$ & $120,831.58$ & $243.00 \mathrm{M}$ & $-1.88 \%$ \\
\hline+13 & $8 / 4$ & $125,291.62$ & $121,599.16$ & $125,318.64$ & $120,829.23$ & $360.14 \mathrm{M}$ & $3.36 \%$ \\
\hline+14 & $8 / 5$ & $125,281.09$ & $125,646.40$ & $126,485.69$ & $123,849.99$ & $268.71 \mathrm{M}$ & $-0.01 \%$ \\
\hline+15 & $8 / 8$ & $129,785.45$ & $128,306.67$ & $130,144.17$ & $127,773.63$ & $256.65 \mathrm{M}$ & $3.60 \%$ \\
\hline+16 & $8 / 9$ & $131,232.84$ & $129,973.89$ & $132,077.36$ & $129,600.57$ & $335.63 \mathrm{M}$ & $1.12 \%$ \\
\hline+17 & $8 / 10$ & $128,901.91$ & $131,461.48$ & $131,969.86$ & $128,227.71$ & 296.44M & $-1.78 \%$ \\
\hline+18 & $8 / 11$ & $131,469.45$ & $128,890.91$ & $131,469.45$ & $128,608.72$ & $230.08 \mathrm{M}$ & $1.99 \%$ \\
\hline+19 & $8 / 12$ & $130,258.57$ & $131,880.59$ & $132,628.31$ & $129,978.79$ & $193.08 \mathrm{M}$ & $-0.92 \%$ \\
\hline+20 & $8 / 15$ & $130,977.52$ & $131,066.37$ & $132,141.97$ & $130,545.97$ & $149.30 \mathrm{M}$ & $0.55 \%$ \\
\hline
\end{tabular}

\section{Conclusion}

The political domain is an important part of the environment in which firms operate. It is also a potential source of instability and uncertainty that affects investor confidence. The forcible removal of a government through a coup is an extreme political event whether the attempt succeeds or fails. Such a failed attempted occurred in Turkey on the $15^{\text {th }}$ July 2016 . In this paper, we applied event study methodology using mean-adjusted returns. Our results indicate that the banks' ARs were statistically insignificant on the first two days of trading after the market had reopened. This may be partly attributed to the speed the coup was quashed and the fact that the markets had been closed in the immediate aftermath, in addition to the weekend effect which relaxes the shock. In line with the efficient market hypothesis, investor reaction could also be explained by the readily available new information as the coup and its defeat played out in real-time through the media. On the third trading day, when a state of emergency was declared these ARs became statistically significant negative. Potentially because this declaration was unexpected and perceived as a potential source of political instability. However, this negative trend was also short-lived. These findings evidence the importance attached to political factors and particularly political instability, in shaping investment decision making. Further analysis compared the mean and median banks' returns to the overall market represented by the BIST100 and BIST30 components. Banks returns were found to exhibit lower levels of volatility than the market as a whole. This may be attributable to the Central Bank of Turkey's stated assurance that it would make unlimited liquidity available in the aftermath of the failed coup. Further research could examine the coup's impact on other market indices such as the BIST100 and BIST30, sectors other than banking, or rather than stock returns could examine the impact on the Turkish Lira's performance.

\section{References}

Acar, M., \& Temiz, H. (2017). Advertising effectiveness on financial performance of banking sector: Turkey case. International Journal of Bank Marketing. 35(4) 
Aktas, H., \& Oncu, S. (2006). The stock market reaction to extreme events: the evidence from Turkey. International Research Journal of Finance and Economics, 6(6), 78-85.

Aguilar, F. J. (1967). Scanning the business environment. Macmillan.

Alsaifi, K., Elnahass, M., \& Salama, A. (2020). Market responses to firms' voluntary carbon disclosure: Empirical evidence from the United Kingdom. Journal of Cleaner Production, 121377.

Amihud, Y., \& Wohl, A. (2004). Political news and stock prices: The case of Saddam Hussein contracts. Journal of banking \& Finance, 28(5), 1185-1200.

Arora, J. (2017). The Impact of the Brexit Referendum on Various World Stock Markets (Doctoral dissertation, The University of North Carolina at Charlotte).

Ayub, Q. M. Y. (2017). The Stock Market Reaction to Extreme Events: The Evidence From Pakistan. International Journal of Information, Business and Management, 9(4), 227-239.

Bash, A., \& Alsaifi, K. (2019). Fear from uncertainty: An event study of Khashoggi and stock market returns. Journal of Behavioral and Experimental Finance, 23, 54-58.

BBC News (2016, 17 July) Turkey's coup attempt: What you need to know https://www.bbc.co.uk/news/world-europe-36816045

BBC News (2016, 21 July) Turkey coup attempt: State of emergency announced https://www.bbc.co.uk/news/world-europe-36852080

Berkman, H., Jacobsen, B., \& Lee, J. B. (2011). Time-varying rare disaster risk and stock returns. Journal of Financial Economics, 101(2), 313-332.

Borsa İstanbul (2019) 2018 Annual Integrated Report Borsaistanbul

Burdekin, R. C., Hughson, E., \& Gu, J. (2018). A first look at Brexit and global equity markets. Applied Economics Letters, 25(2), 136-140.

Brown, S. J., \& Warner, J. B. (1985). Using daily stock returns: The case of event studies. Journal of financial economics, 14(1), 331.

Chen, A. H., \& Siems, T. F. (2004). The effects of terrorism on global capital markets. European Journal of Political Economy, 20(2), 349-366.

Chira, I., Madura, J., \& Viale, A. M. (2013). Bank exposure to market fear. Journal of Financial Stability, 9(4), $451-459$.

Cole, R. A., Moshirian, F., \& Wu, Q. (2008). Bank stock returns and economic growth. Journal of Banking \& Finance, 32(6), 9951007.

Cornett, M. M., McNutt, J. J., \& Tehranian, H. (2009). The financial crisis, internal corporate governance, and the performance of publicly-traded US bank holding companies. Internal Corporate Governance, and the Performance of Publicly-Traded US Bank Holding Companies (January 22, 2009).

European Central Bank (2006, 20 June) What drives EU banks' stock returns?

Feng, Y. (1997). Democracy, political stability and economic growth. British Journal of Political Science, $391-418$.

Günay, S. (2016). Is political risk still an issue for Turkish stock market?. Borsa Istanbul Review, 16(1), 21-31.

Günay, S. (2019). An analysis through credit default swap, asset swap and zero-volatility spreads: Coup attempt and Bist 100 volatility. Borsa Istanbul Review, 19(2), 158-170.

Hewison, K., (2008). A Book, the King and the 2006 Coup. Journal of Contemporary Asia, 38(1), pp.190-211.

Jadallah, N., \& Bhatti, F. (2020). Political instability and sustainable green supply chain management. Management Science Letters, 10(6), 1169-1178.

Kartal, M. T., İbiş, C., \& Çatıkkaş, Ö. (2018). Adequacy of audit committees: A study of deposit banks in Turkey. Borsa İstanbul Review, 18(2), 150-165.

Koc, C. Courcoulas, C. and Viscusi, G. (2016) Turkey Moves to Calm Investors After Coup Attempt Quashed. Bloomberg

Lehkonen, H., \& Heimonen, K. (2015). Democracy, political risks and stock market performance. Journal of International Money and Finance, 59, 77-99.

Mirzaei, Z., Hamidian, M., \& Valahzaghard, M. (2014). Investigating banks' financial structure on profitability and price volatility of banks' shares: Evidence from Tehran Stock Exchange. Management Science Letters, 4(10), 2221-2228.

Motamedi, P. (2013). Investigating different factors influencing on return of private banks. Management Science Letters, 3(9), 24672472.

Peni, E., \& Vähämaa, S. (2012). Did good corporate governance improve bank performance during the financial crisis?. Journal of Financial Services Research, 41(1-2), 19-35.

Rigobon, R., \& Sack, B. (2005). The effects of war risk on US financial markets. Journal of Banking \& Finance, 29(7), 1769-1789.

Sinha, P. (2015). Stocks' pricing dynamics and behavioral finance: A review. Management Science Letters, 5(9), 797-820.

Straetmans, S. T., Verschoor, W. F., \& Wolff, C. C. (2008). Extreme US stock market fluctuations in the wake of 9/11. Journal of Applied Econometrics, 23(1), 17-42.

Weigand, R. A. (2016). The performance and risk of banks in the US, Europe and Japan post-financial crisis. Investment Management and Financial Innovations, 13(4), 75-93.

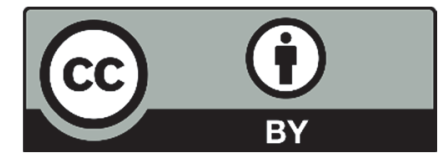

(C) 2020 by the authors; licensee Growing Science, Canada. This is an open access article distributed under the terms and conditions of the Creative Commons Attribution (CC-BY) license (http://creativecommons.org/licenses/by/4.0/). 